\title{
Antithrombotic Activity of Extracts from the Aromatic Herb Elsholtzia splendens
}

\author{
Won Shik Kim ${ }^{1}$ and Yong Lim $^{2 \dagger}$ \\ ${ }^{I}$ Department of Clinical Laboratory Science, Daejeon Health Institute of Technology, Daejeon 34504, Korea \\ ${ }^{2}$ Department of Clinical Laboratory Science, Dong-Eui Univerisity, Busan 47340, Korea
}

\begin{abstract}
Elsholtzia splendens, which grows on moist soil of mountainous regions, is widely distributed at all regions of Korea, especially at Mountain Ji ri. It is categorized as a Labiatae plant which is dried aerial part. It has the following medicinal properties; removal of fever, alleviation of pain, a good antiphlogistic agent as well as antibacterial effects. However, the effects of E. splendens on thrombosis and platelet activation are not precisely understood. We performed this study to develop antithrombotic agents from oriental medicine herb extracts. E. splendens inhibited platelet aggregation induced by arachidonic acid and U46619 in a concentration dependent manner. E. splendens did not show an effect on anticoagulation as determined by prothrombin time (PT) or activated partial thromboplastin time (aPTT). We also tested the effects of $E$. splendens using a carotid artery thrombosis rat model induced by $35 \% \mathrm{FeCl}_{3}$ treatment. E. splendens significantly inhibited thrombus weight compared with the control group. These results show that $E$. splendens may be developed as a potential antiplatelet activity agent for treatment of cardiocerebrovascular disease and atherosclerosis.
\end{abstract}

Key Words: Elsholtzia splendens, Antiplatelet, Antithrombotic activity, Platelet aggregation

최근 생활수준의 향상과 더불어 건강에 대한 관심이 급 속히 높아져 가고 있는 추세이며, 특히 현대 도시 생활자 들은 40 대 중반부터 찾아오는 성인병의 예방과 치료에 대 한 관심이 대단히 높다. 성인병 중 고혈압, 동맥경화, 심장 병, 뇌졸중 등은 대표적인 순환기계 질병으로 지금까지 치료약제가 다수 개발되어 있음에도 불구하고 개선되지 않고 있다. 뇌혈관계 및 심혈관계 질환은 뇌출혈, 뇌혈전, 심부전, 심근경색 등으로 대표되며 순환 혈관계 질환은 일 차적으로 혈관 내에 혈전이 생성됨으로써 혈관의 폐쇄와 혈류 장애를 초래하며, 심장이나 뇌조직 등에 허혈성 세 포 손상을 일으킴으로써 발병하는 질병이다. 혈전 형성은 심장 마비 또는 뇌졸중 등의 폐쇄성 동맥질환 유발의 주 된 원인으로 작용할 뿐만 아니라 동맥경화의 발생과 악
화에도 주요한 원인으로 인식되고 있다. 동맥경화용제는 크게 심혈관계 약물인 고지혈증 치료제와 혈액 관련 약물 인 항혈전, 혈소판 응집 억제제(antithrombotics, antiplatelet agent), 항응고제(anticoagulant), 혈전용해제(fibrinolytics)로 대표된다. 이 중 혈액 관련 약물은 주로 혈전(thrombus)에 초점이 맞춰져 있는데 혈관 내의 혈전은 동맥경화를 비롯 한 심혈관질환의 주요 원인이 되며 혈전의 제거는 심혈관 질환의 예방과 치료에 중요한 요소이다. 혈전은 일반적으 로 혈관이 손상을 받아 출혈이 일어난 후 혈소판이 응집 되면서 혈액이 혈관 또는 조직 내에서 응고됨으로서 생성 된다(Wolberg, 2008). 정상적인 경우 혈전은 plasmin 등과 같은 혈전용해효소에 의해 체내에서 자연적으로 분해되나, 혈관 또는 조직 내에 과도한 양의 혈전이 축적되거나 혈

*Received: August 8, 2017 / Revised: August 28, 2017 / Accepted: August 28, 2017

${ }^{\dagger}$ Corresponding author: Yong Lim. Department of Clinical Laboratory Science, Dong-Eui University, 176 Eomgwangno, Busanjin-gu, Busan 47340, Korea. Tel: +82-51-890-2684, Fax:+82-505-182-6877, e-mail: yonglim@deu.ac.kr

(C) The Korean Society for Biomedical Laboratory Sciences. All rights reserved.

(9This is an Open Access article distributed under the terms of the Creative Commons Attribution Non-Commercial License (http://creativecommons.org/licenses/by-nc/3.0/) which permits unrestricted non-commercial use, distribution, and reproduction in any medium, provided the original work is properly cited. 
전용해와 관련된 생리학적 기구가 정상적이지 못할 경우 에는 혈액의 흐름이 제한되고 결국은 특정조직에 산소와 영양물질을 공급하지 못하게 되어 심근경색, 뇌경색 및 폐동맥경색증과 같은 혈전증(thrombosis)을 유발하여 결국 장애나 사망에 이르게도 한다(Mizuno et al., 2008; Wolberg, 2007).

혈전성 질환의 일차 발병 후 재발방지, 혈전성 질환의 진행차단 또는 예방 목적으로 aspirin, ticlopidine 등의 항 혈소판 작용 약물들이 주로 사용되고 있으나, 보다 효과 적이고 안전성이 확보된 항 혈소판제의 개발에 많은 연구 가 집중되고 있다. 그러나 현재 사용되고 있는 약물들의 경우 그 효과가 완벽하지 못해 우수한 항혈전 기능을 가 진 새로운 약물의 개발이 요구된다(Chen et al., 2015).

꽃향유(Elsholtzia splendens)는 꿀풀과 향유속에 속하는 식물로서 아시아와 지중해 연안에 많이 분포하고, 붉은 향유, 해주 향유라는 속명을 가지고 있다. 우리나라에는 남부와 중부에 분포하고 있다. 국내에 자생하는 향유속에 는 꽃향유 이외에 향유(E. ciliata), 좀향유(E. minima) 및 가 는잎향유(E. angustifolia)가 있다. 모두 1년생 초본 방향성 식물로 식용, 관상용, 밀원용, 약용에 쓰이는데, 어린잎은 식용한다. 민간에서는 개화기에 전초를 생약으로 사용하 는데 발한, 해열, 이뇨, 수종, 지혈 등에 약으로 이용한다 (Heo, 2000). 따라서 본 연구는 안전성이 확보된 식용자원 인 꽃향유 추출물의 항혈소판 응집 및 항혈전 활성 평가 를 수행하여 혈관질환에 사용할 수 있는 또 다른 약리 효능을 알아보고자 하였다.

실험에 사용한 7주령의 수컷 Spague-Dewley (SD) rat은 (주)오리엔트바이오에서 구입하여 1주 이상 본 실험 사 육장환경에 적응시킨 후 스트레스를 최소화하고, 몸무게 250 300 g의 male을 실험에 사용하였다. 물과 사료는 자 유롭게 섭취하도록 하였고 사육장 실내의 온도는 $22 \pm 2{ }^{\circ} \mathrm{C}$, 습도는 $50 \pm 10 \%$, 조명은 12 시간 명암 주기가 되도록 조 절하였다. 본 실험에 사용된 모든 실험동물의 사육 및 처 치는 동의대학교 동물실험윤리위원회의 승인(DEU-15-032) 을 얻어 수행하였다. 시험물질인 꽃향유(Elsholtzia splendens)는 한국식물추출물은행에서 분양받아 실험에 사용하 였다. 각각 실험에 사용된 시료는 다음과 같이 사용하였 다. 경동맥혈전 유발 동물모델을 이용한 혈전용해는 $20 \%$ dimethyl sulfoxide (DMSO, Sigma, St. Louis, MO, USA), prothrombin time (PT)과 activated partial thromboplastin time (aPTT)은 $10 \% \mathrm{DMSO}$, 혈소판 응집은 $3 \% \mathrm{DMSO}$ 에 녹여 실험에 사용하였다.
Washed platelet의 조제를 위한 혈액은 흰쥐를 ethyl ether 로 마취하고, 항응고제 $0.15 \mathrm{M}$ sodium citrate를 혈액과 1:9 (v/v)의 비율이 되도록 함유한 주사기로 복대동맥으로부 터 채혈하였다. Platelet rich plasma (PRP)는 1,000 rpm에서 10 분간 원심분리하여 상등액의 $\mathrm{PRP}$ 를 얻었고, 계속하여 $2,500 \mathrm{rpm}$ 에서 15 분간 원심분리하고, 침전된 혈소판을 washing buffer에 현탁시켜서 washed platelet로 하였다(Jin et al., 2008). 최종 혈소판의 농도는 $3 \times 10^{8}$ platelet $/ \mathrm{mL}$ 이 되도록 조정하여 platelet poor plasma (PPP)을 얻어 실험에 사용하였다.

혈소판 응집 억제능은 Aggregometer (Chrono-Log Co., Ltd., Havertown, PA, USA)를 이용한 탁도 측정법으로 측정 하였다(Jin et al., 2008). Washed platelet를 $37^{\circ} \mathrm{C}$ 에서 3 분간 incubation 시킨 후 농도별로 시료를 처리하고 2 분 후 혈 소판 응집을 유도하는 물질 collagen $(10 \mu \mathrm{g} / \mathrm{mL})$, arachidonic acid $(100 \mu \mathrm{M}), \mathrm{U} 46619(1 \mu \mathrm{M})$ 그리고 thrombin $(0.05 \mathrm{U} / \mathrm{mL})$ 로 응집을 유도하였으며, 10 분간 측정한 후 억제 정도를 계산하였다. 억제 정도(\%)는 시료를 처리하지 않은 것을 control로 하여, 아래와 같은 방법으로 구하였다.

Inhibition $=(\mathrm{A}-\mathrm{B}) / \times 100$

$\mathrm{A}$ : DMSO만 처리한 대조군의 aggregation \%

$\mathrm{B}$ : 꽃향유 추출물을 처리한 실험군의 aggregation $\%$

혈액응고의 지표인 $\mathrm{PT}$ 와 $\mathrm{aPTT}$ 을 측정하였다. $0.38 \%$ sodium citrate가 포함되도록 채혈한 후 $2,000 \mathrm{rpm}$ 에서 15 분 간 원심분리하여 PPP를 얻었다. Reagent reservoir에 plasma $500 \mu \mathrm{L}$ 와 측정농도의 꽃향유 추출물을 넣은 다음 $37^{\circ} \mathrm{C}$ 에 서 5 분간 미리 incubation 시킨 후 $\mathrm{PT}$ 와 $\mathrm{aPTT}$ 를 동시에 측정할 수 있는 자동혈액응고 분석기 ACL-3000 (Instrumentation Laboratory)을 이용하여 측정하였다.

경동맥혈전 유발 동물모델을 제작하기 위해 $\mathrm{FeCl}_{3}$ 를 이 용하여 경동맥혈전을 유발하였다(Park et al., 2011). 동물 실험실에서 적응된 흰쥐를 $70 \% \mathrm{~N}_{2} \mathrm{O}$ 와 $28.5 \% \mathrm{O}_{2}$ 가스에 $2.0 \%$ 엔플루란(enflurane, 중외제약, 한국)을 혼합시킨 마 취가스를 사용하여 흡입마취 후 수술대에 고정하고, 흡입 전신 마취를 계속하여 유지하였다. 목의 정중부를 절개 를 하고 미주신경이 손상되지 않도록 주의하여 우측 총 경동맥(common carotid, $\mathrm{CCA}$ )을 찾아 확인한 후 노출시켰 다. 그리고 doppler flow prove를 경동맥에 위치시켜 모니 터를 통하여 혈행을 관찰하였다. 혈관에 filter paper $(2 \mathrm{~mm}$ square)를 대어 3 분 간 $35 \% \mathrm{FeCl}_{3}$ 를 가하였다. 3 분이 지나 
Table 1. Inhibitory activities of Elsholtzia splendens extracts on agonist induced rat platelet aggregation

\begin{tabular}{ccccc}
\hline \hline & \multicolumn{3}{c}{ Inhibition $(\%)$} \\
\hline $\begin{array}{c}\text { Elsholtzia splendens extracts } \\
(\mu \mathrm{g} / \mathrm{mL})\end{array}$ & $\begin{array}{c}\text { Collagen } \\
(10 \mu \mathrm{g} / \mathrm{mL})\end{array}$ & $\begin{array}{c}\text { Arachidonic acid } \\
(100 \mu \mathrm{M})\end{array}$ & $\begin{array}{c}\mathrm{U} 46619 \\
(1 \mu \mathrm{M})\end{array}$ & $\begin{array}{c}\text { Thrombin } \\
(0.05 \mathrm{U} / \mathrm{mL})\end{array}$ \\
\hline 100 & 12.9 & 22.2 & 27.2 & 19.3 \\
200 & 13.1 & 31.1 & 45.9 & 24.1 \\
300 & 27.3 & 90.8 & 71.3 & 32.9 \\
\hline
\end{tabular}

Table 2. Effects of Elsholtzia splendens extracts on blood coagulation

\begin{tabular}{ccc}
\hline \hline & Inhibition (\%) \\
\hline $\begin{array}{c}\text { Elsholtzia splendens } \\
\text { extracts }(\mu \mathrm{g} / \mathrm{mL})\end{array}$ & $\begin{array}{c}\mathrm{PT} \\
\text { (second) }\end{array}$ & $\begin{array}{c}\text { aPTT } \\
\text { (second) }\end{array}$ \\
\hline 100 & $17.3 \pm 0.3$ & $22.2 \pm 0.1$ \\
200 & $17.4 \pm 0.1$ & $22.2 \pm 0.3$ \\
300 & $17.2 \pm 0.2$ & $22.3 \pm 0.1$ \\
Blank & $17.3 \pm 0.1$ & $22.1 \pm 0.2$ \\
\hline
\end{tabular}

면 filter paper를 제거하고 경동맥을 세척하고 30 분 간 관 찰하였다. 어느 정도의 시간이 지나면 혈전이 형성이 되 며 30 분 후 혈전이 생긴 부위의 혈전을 조심스럽게 박리 한 후 무게를 측정하였다.

모든 측정 결과는 3 반복 이상의 독립적인 실험에서 도 출된 대표값의 평균(mean)과 표준편차(standard deviation; SD)로 나타내었다. SPSS statistics 19 program (IBM, Amonk, $\mathrm{NY}, \mathrm{USA})$ 을 이용하여 ANOVA test를 시행하였으며 구체적 인 사후 검정은 Duncan's multiple range test를 이용하여 $P$ $<0.05$ 수준에서 유의성을 검정하였다.

항혈소판 응집 효과를 검색하기 위해 본 연구에서는 생 리적 환경에서 혈소판 응집을 일으키는 collagen, arachidonic acid, U46619, thrombin으로 유도한 혈소판 응집반응 에서 꽃향유 추출물이 미치는 영향을 검토하였다. 그 결 과 꽃향유 추출물은 arachidonic acid와 U46619로 유도한 혈소판 응집반응에 대해 농도 의존적 억제 활성 경향을 보였으며, 특히 arachidonic acid로 유도된 혈소판 응집반응 에 대해 꽃향유 추출물 최고 농도에서는 $90.8 \%$ 억제율을 보였다(Table 1).

심혈관질환을 예방하고 뇌졸중을 예방하기 위해 대표적 으로 아스피린을 복용하지만 출혈이 일어났을 때 지혈작

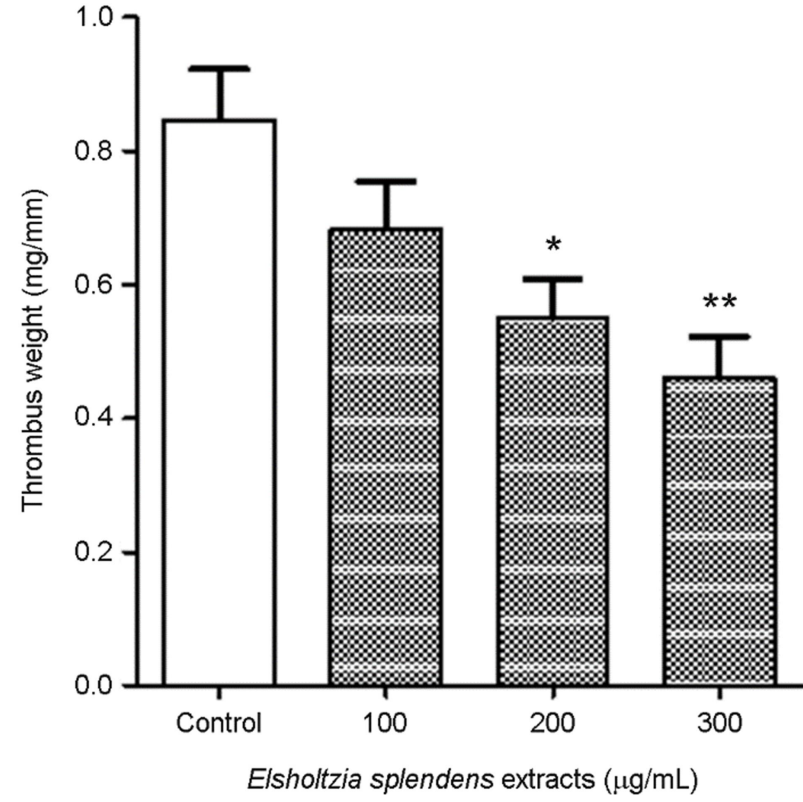

Fig. 1. The Effects of Elsholtzia splendens extracts on thrombus weight. Thrombus weight were determined 30 min after $\mathrm{FeCl}_{3}$ induced injury. All values showed mean \pm SD. Tested by one-way ANOVA and Tukey's multiple range test. Statistically significant compared with control group $(* P<0.05, * * P<0.01)$.

용을 방해하는 부작용이 있어 혈액응고 기전에 영향을 주지 않고 항혈소판 작용을 나타내는 물질을 찾고자 많 은 연구자들이 연구하고 있다. 꽃향유 추출물이 혈액 응 고에 미치는 영향을 실험한 결과 prothrombin time (PT) 또 는 activated partial thromboplastin time (aPTT)에 전혀 유의 적인 영향을 주지 않았다. 따라서 꽃향유 추출물의 항혈 전 작용은 혈소판 응집억제 작용에 국한되어 있음을 확인 할 수 있었다(Table 2).

꽃향유 추출물의 항혈전 효과를 보기 위하여 $\mathrm{FeCl}_{3}$ 를 이용하여 경동맥혈전증 유발 동물모델을 제작하여 혈전무 
게를 측정하였다. 꽃향유 추출물을 $100,200,300 \mu \mathrm{g} / \mathrm{mL}$ 의 농도로 처리하여 혈전무게를 측정한 결과 $100 \mu \mathrm{g} / \mathrm{mL}$ 투 여군은 유의성이 나타나지 않았고, $200 \mu \mathrm{g} / \mathrm{mL}$ 투여군 $(P<$ $0.5), 300 \mu \mathrm{g} / \mathrm{mL}$ 투여군 $(P<0.01)$ 에서 유의한 감소를 나타 냈다(Fig. 1).

현재 혈관계 질환을 유발하는 혈전의 예방과 치료방법 으로 식이조절, 운동요법, 약물요법 등이 있으며, 약물요 법에는 크게 심혈관계 약물인 고지혈증 치료제와 혈액 관 련 약물인 항혈전, 항혈소판 응집 억제제, 항응고제 등이 사용되고 있다. 하지만 이러한 치료제들은 가격이 매우 높 을 뿐만 아니라 urokinase를 제외하고는 경구투여가 불가 능하며(Liu et al., 2002), 모두 정제된 화학물질로 인체에 투여하였을 때 지혈과다억제, 불임, 소화기장애 등의 여러 부작용을 야기한다(Burggraf et al., 2008). 따라서 최근에는 천연물로부터 보다 경제적이고 인체에 무해하며 혈전을 선택적으로 용해시키고 혈관 내에서 혈소판의 응집을 저 해하여 혈전예방의 효과를 나타낼 수 있는 물질의 탐색이 필요한 실정이다(Swenson et al., 2005; Mine, 2005). 따라서 본 연구에서 꽃향유 추출물의 항혈소판 응집 및 항혈전 활성 평가를 수행하여 혈관질환에 사용할 수 있는 천연물 질 효능 평가를 하고자 하였다. 그 결과 꽃향유 추출물은 혈액응고 기전에 영향을 주지 않으며 항혈소판 효과와 항 혈전 작용으로 혈관질환의 치료 및 예방물질로 이용할 수 있을 뿐만 아니라 천연물신약 연구 개발에 기여할 수 있 을 것으로 사료된다.

\section{ACKNOWLEDGEMENTS}

이 논문은 2015년도 대전보건대학교 교내연구비 지원 에 의한 논문임.

\section{CONFLICT OF INTEREST}

The authors have no conflicts of interest to disclose.

\section{REFERENCES}

Burggraf D, Vosko MR, Schubert M, Stassen JM, Hamann GF. Different therapy options protecting microvasculature after experimental cerebral ischaemia and reperfusion. Thrombosis and Haemostasis. 2010. 103: 891-900.

Chen C, Yang FQ, Zhang Q, Wang FQ, Hu YJ, Xia ZN. Natural products for antithrombosis. Evidence-Based Complementary and Alternative Medicine. 2015: 876426.

Heo J. Donguibogam. Namsandang. 2000. 660.

Jin YR, Im JH, Park ES, Cho MR, Han XH, Lee JJ, Lim Y, Kim TJ, Yun YP. Antiplatelet activity of epigallocatechin gallate is mediated by the inhibition of PLCgamma2 phosphorylation, elevation of PGD2 production, and maintaining calciumATPase activity. Journal of Cardiovascular Pharmacology. 2008. 51: 45-54.

Liu S, Jiang S, Wu Z, Lv L, Zhang J, Zhu Z, Wu S. Identification of inhibitors of the HIV-1 gp41 six-helix bundle formation from extracts of Chinese medicinal herbs Prunella vulgaris and Rhizoma cibotte. Life Sciences. 2002. 71: 1779-1791.

Mine Y, Wong AHK, Jiang B. Fibrinolytic enzymes in Asian traditional fermented foods. Food Research International. 2005. 38: 243-250.

Mizuno T, Sugimoto M, Matsui H, Hamada M, Shida Y, Yoshioka A. Visual evaluation of blood coagulation during mural thrombogenesis under high shear blood flow. Thrombosis Research. 2008. 121: 855-864.

Park ES, Lim Y, Lee SH, Kwon BM, Yoo HS, Hong JT, Yun YP. Antiplatelet activity of obovatol, a biphenolic component of Magnolia Obovata, in rat arterial thrombosis and rabbit platelet aggregation. Journal of Atherosclerosis and Thrombosis. 2011. 18: 659-669.

Swenson S, Markland FS Jr. Snake venom fibrin(ogen)olytic enzymes. Toxicon. 2005. 45: 1021-1039.

Wolberg AS, Campbell RA. Thrombin generation, fibrin clot formation and hemostasis. Transfusion and Apheresis Science. 2008. 38: 15-23.

Wolberg AS. Thrombin generation and fibrin clot structure. Blood Reviews. 2007. 21: 131-142.

https://doi.org/10.15616/BSL.2017.23.3.277

Cite this article as: Kim WS, Lim Y. Antithrombotic Activity of Extracts from the Aromatic Herb Elsholtzia splendens. Biomedical Science Letters. 2017. 23: 277-280. 